\title{
Specific detection of Mycobacterium paratuberculosis by DNA hybridisation with a fragment of the insertion element IS900
}

\author{
M T Moss, E P Green, M L Tizard, Z P Malik, J Hermon-Taylor
}

\begin{abstract}
This paper describes the evaluation of a newly developed DNA probe for Mycobacterium paratuberculosis. DNA probe PCR278 is a 278 bp fragment obtained by polymerase chain reaction (PCR) amplification of the 5 '-region of IS900, an insertion element contained in the genome of $M$ paratuberculosis. This DNA probe can specifically distinguish $M$ paratuberculosis from a wide range of other organisms, including members of the $M$ avium-M intracellulare complex. When used in conjunction with the PCR amplification technique DNA probe PCR278 could detect as little as $10 \mathrm{fg}$ (equivalent to two genomes) starting material of $M$ paratuberculosis genomic DNA. Use of PCR amplification assays based on IS900, for the detection of $M$ paratuberculosis, and homologous IS elements found in disease isolates of $M$ avium should greatly help our understanding of the role of these organisms in Crohn's disease and other chronic inflammatory disorders.
\end{abstract}

A mycobacterial aetiology for Crohn's disease has long been suspected ${ }^{12}$ but it is only in the last few years that mycobacteria have been isolated from Crohn's disease tissue. Burnham et $a l^{3}$ isolated Mycobacterium kansasii from the lymph node of one of 27 patients with Crohn's disease; Chiodini et $a l^{4}$ isolated a Mycobacterium species, subsequently shown to be $M$ paratuberculosis, ${ }^{5-8}$ from two of 11 cases of Crohn's disease but not from 3 cases of ulcerative colitis. Graham et al ${ }^{9}$ isolated mycobacteria, mainly members of the $M$ avium$M$ intracellulare and $M$ fortuitum complexes, from nine of 59 cases of Crohn's disease but also isolated mycobacteria from nine of 19 cases of ulcerative colitis and from 18 of 27 non-inflammatory disease control subjects. The greatest interest has been generated by the isolation of $M$ paratuberculosis. This pathogenic organism is the causative agent of Johne's disease, ${ }^{10}$ a chronic ileitis/colitis which causes wasting disease of cattle and has many similarities for Crohn's disease. ${ }^{11}{ }^{12}$ Human isolates of $M$ paratuberculosis have only been isolated from Crohn's disease patients. ${ }^{13}$

Determining a role, if any, for $M$ paratuberculosis in Crohn's disease requires precise and sensitive probing of Crohn's disease tissue for the presence of this organism. We have recently sequenced and characterised ${ }^{14}$ an insertion element (IS900), occurring 15-20 times in the genome of $M$ paratuberculosis, and in this paper we report the use of a DNA probe, based on a unique portion of IS 900 , specifically to detect $M$ paratuberculosis.

\section{Methods}

MYCOBACTERIAL SPECIES

The 27 mycobacterial strains used in our study are given in the legend to Figure 1 and were obtained from Dr J L Stanford (University College and Middlesex School of Medicine). The original respective sources of these strains were as described previously. ${ }^{15}$

\section{GROWTH CONDITIONS}

Strains were grown on Lowenstein-Jensen medium at $35^{\circ} \mathrm{C}$ for the appropriate incubation

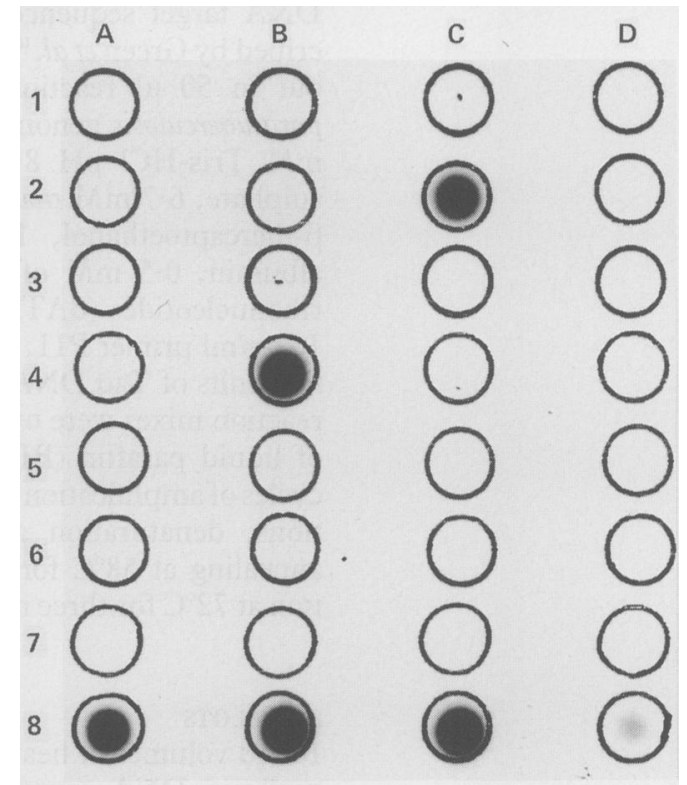

Figure 1: Dot blot hybridisation with ${ }^{32 \mathrm{P}}$-labelled PCR278. 200 ng aliquots (unless otherwise stated) of genomic DNA from 27 mycobacterial strains were dot blotted onto a nylon membrane: (1A) Mycobacterium thermoresistibile, (1B) $M$ diernhoferi, (1C) $M$ bovis, BCG, (1D) $M$ duvalii; (2A) $M$ flavescens, (2B) M bovis, (2C) M paratuberculosis, $100 \mathrm{ng}$ (2D) $M$ smegmatis; (3A) $M$ intracellulare, (3B) $M$ avium, (3C) $M$ marinum, (3D) $M$ rhodesiae; (4A) $M$ neoaurum, (4B) $M$ paratuberculosis, $100 \mathrm{ng}$, (4C) $M$ gilvum, (4D) $M$ nonchromogenicum; (5A) $M$ chitae, (5B) M tuberculosis, (5C) $M$ malmoense, (5D) $M$ kansasii; (6A) $M$ gastri, (6B) $M$ intracellulare, (6C) $M$ phlei, (6D) $M$ simiae; (7A) $M$ vaccae, (7B) $M$ fortuitum, (7C) $M$ gordonae, (7D) $M$ asiaticum; (8A) M paratuberculosis, $200 \mathrm{ng}$, (8B) M paratuberculosis, $100 \mathrm{ng}$, (8C) M paratuberculosis, $50 \mathrm{ng}$, (8D) $M$ paratuberculosis, 5 ng. After hybridisation at $65^{\circ} \mathrm{C}$ for 16 hours the membrane was washed with $0 \cdot 1 \times S S C$ ( $0.15 \mathrm{M}$ sodium chloride; $0.015 \mathrm{M}$ sodium citrate, $\mathrm{pH} 7)$; $0 \cdot 1 \%$ sodium dodecyl sulphate then exposed to an $\mathrm{x}$ ray film for three hours at $-70^{\circ} \mathrm{C}$. 
periods. In the case of $M$ paratuberculosis, mycobactin J was present at a final concentration of $1 \mu \mathrm{g} / \mathrm{ml}$.

\section{GENOMIC DNA EXTRACTION}

Cells were harvested and genomic DNA extracted in accordance with our previously described protocol.$^{15}$ Briefly, cells were lysed after sequential treatment with $100 \mathrm{mg} / \mathrm{ml}$ subtilisin (Sigma) at $37^{\circ} \mathrm{C}$ for 18 hours, $200 \mathrm{mg} / \mathrm{ml}$ lysozyme (Sigma) at $50^{\circ} \mathrm{C}$ for five hours, then $30 \mathrm{mg} / \mathrm{ml}$ pronase (Calbiochem) and $1 \%$ sodium dodecyl sulphate at $37^{\circ} \mathrm{C}$ for 20 hours. Two phenol chloroform extractions were carried out and the DNA was recovered by ethanol precipitation.

\section{PCR PRIMERS}

Two oligonucleotide primers (P11 and P36) were custom synthesised for PCR amplification (Oswel DNA Service, Edinburgh). P11: 5'-CGTCGTTAATAACCATGCAG-3' and P36: 5'-GGCCGTCGCTTAGGCTTCGA-3' are found in the 5 '-region of IS 900 (data not shown), are complementary to the sense and antisense strands of IS 900 , respectively, and allow amplification of a $278 \mathrm{bp}$ fragment (DNA probe PCR278).

\section{PCR CONDITIONS}

Amplification of $M$ paratuberculosis genomic DNA target sequences was performed as described by Green et al. ${ }^{16}$ Amplification was carried out in $50 \mu \mathrm{l}$ reaction volumes containing $M$ paratuberculosis genomic DNA (10 ng-1 fg), 67 $\mathrm{mM}$ Tris- $\mathrm{HCl}$ pH $8 \cdot 8,16 \cdot 6 \mathrm{mM}$ ammonium sulphate, $6.7 \mathrm{mM}$ magnesium chloride, $10 \mathrm{mM}$ $\beta$-mercaptoethanol, $170 \mu \mathrm{g} / \mathrm{ml}$ bovine serum albumin, $0.5 \mathrm{mM}$ of each of the four deoxyribonucleotides (dATP, dCTP, dGTP, dTTP), $10 \mu \mathrm{g} / \mathrm{ml}$ primer $\mathrm{P} 11,10 \mu \mathrm{g} / \mathrm{ml}$ primer $\mathrm{P} 36$, and five units of Taq DNA polymerase (Cetus). The reaction mixes were overlaid with $50 \mu$ l volumes of liquid paraffin (BDH) then subjected to 30 cycles of amplification under the following conditions: denaturation at $93^{\circ} \mathrm{C}$ for one minute; annealing at $58^{\circ} \mathrm{C}$ for one minute; polymerisation at $72^{\circ} \mathrm{C}$ for three minutes.

DOT BLOTS

$100 \mathrm{ul}$ volumes of heat denatured mycobacterial genomic DNA samples (200 ng-50 pg) were spotted onto nylon membranes (Hybond-N; Amersham) with the aid of a Bio-Dot unit (Bio$\mathrm{Rad})$. Membranes were washed in $2 \times$ SSC ( $1 \times$ SSC consists of $0.15 \mathrm{M}$ sodium chloride; 0.015 $M$ sodium citrate, $\mathrm{pH} \mathrm{7),} \mathrm{air} \mathrm{dried} \mathrm{then} \mathrm{ultra-}$ violet illuminated for three minutes to allow cross linking of the DNA to the membrane.

\section{HYBRIDISATION}

The membranes were prehybridised at $65^{\circ} \mathrm{C}$ in buffer consisting of $3 \times \mathrm{SSC} ; 0 \cdot 1 \%(\mathrm{w} / \mathrm{v})$ bovine serum albumin (fraction V; Sigma); $0 \cdot 1 \%(\mathrm{w} / \mathrm{v})$ ficoll (Pharmacia); $0 \cdot 1 \%(\mathrm{w} / \mathrm{v})$ polyvinylpyrrolidone (Sigma); $0 \cdot 5 \%(\mathrm{w} / \mathrm{v})$ sodium dodecyl
Bacterial strains

\begin{tabular}{ll}
\hline Aeromonas hydrophila Porton & Klebsiella pneumoniae CI \\
Down 13109 & Lactobacillus rhamnosus NCIB \\
Alcaligenes odorans NCTC & 8010 \\
10388 & Listeria monocytogenes CI \\
Arthrobacter globiformis NCIB & Nocardia asteroides ATCC \\
8907 & 3318 \\
Bacillus subtilis CI & Nocardia brasiliensis IMRV \\
Bacteroides asaccharolyticus & 800 \\
NCTC 9337 & Peptococcus asaccharolyticus \\
Bacteroides fragilis NCTC 8343 & NCTC 11461 \\
Brevibacterium lipolyticum & Peptostreptococcus magnus CI \\
IAM 1413 & Propionibacterium acnes VPI \\
Candida albicans CI & 0162 \\
Cellulomonas biazotea NCIB & Propionibacterium avidum VPI \\
8077 & 0589 \\
Cellulomonas fimi NCTC 7547 & Proteus mirabilis CI \\
Campylobacter jejuni CI & Pseudomonas aeruginosa \\
Clostridium difficile CI & NCTC 10662 \\
Clostridium perfringens CI & Rhodococcus corallinus NCTC \\
Clostridium septicum CI & 10668 \\
Corynebacterium JK NCTC & Rhodococcus species NCIB \\
11915 & 9784 \\
Corynebacterium minutissimum & Rothia dentocariosa NCTC \\
NCTC 10284 & 10207 \\
Enterobacter cloacae CI & Salmonella enteritidis CI \\
Escherichia coli NCTC 10418 & Staphylococcus aureus NCTC \\
Eubacterium aerofaciens NCTC & 6571 \\
11838 & Staphylococcus epidermidis CI \\
Eubacterium lentum NCTC & Streptococcus faecalis CI \\
11813 & Streptococcus milleri CI \\
Fusobacterium varium NCTC & Streptococcus pneumoniae CI \\
10560 & Streptomyces coelicolor A3 (2) \\
Gardinerella vaginalis CI & Wolinella recta NCTC 11489 \\
Helicobacter pylori CI & Yersinia enterocolitica CI \\
\hline &
\end{tabular}

$\mathrm{CI}=$ clinical isolate.

sulphate (SDS) (Sigma); 10\% (w/v) dextran sulphate (Pharmacia); and $100 \mu \mathrm{g} / \mathrm{ml}$ sheared and denatured salmon sperm DNA (Sigma) for at least one hour. ${ }^{32 \mathrm{P}}$-labelled DNA probes were prepared by the random hexanucleotide priming technique of Feinberg and Vogelstein. ${ }^{17}$ After denaturation by boiling DNA probes were added to the prehybridised membranes, together with fresh hybridisation buffer. Hybridisation was carried out at $65^{\circ} \mathrm{C}$ overnight. Membranes were washed at $65^{\circ} \mathrm{C}$ in $3 \times \mathrm{SSC} ; 0.1 \%$ SDS for $2 \times 30$ minutes, in $1 \times \mathrm{SSC} ; 0 \cdot 1 \%$ SDS for $2 \times 30$ minutes, and finally in $0 \cdot 1 \times$ SSC; $0 \cdot 1 \%$ SDS for $2 \times 30$ minutes. Membranes were exposed to $\mathrm{X}$-Omat film (Kodak) at $-70^{\circ} \mathrm{C}$ for periods of between three and 16 hours.

\section{Results}

SPECIFICITY OF DNA PROBE PCR278

PCR amplification of $M$ paratuberculosis genomic DNA with the oligonucleotide primers P11 and $P 36$ produces an amplification product of $278 \mathrm{bp}$ (PCR278). To test the specificity of product PCR278 as a DNA probe, a dot blot containing genomic DNA from 27 mycobacterial strains was prepared. After hybridisation of this dot blot with ${ }^{32 P}$-labelled PCR278 positive signals were obtained only with $M$ paratuberculosis, as seen in Figure 1. A second dot blot, containing genomic DNA from a further 46 bacterial strains (Table), was similarly prepared and probed with ${ }^{32 P}$-labelled PCR278. These strains were chosen on the basis of being common gut commensals or for having previously been implicated in Crohn's disease. No positive signals were observed on this dot blot (data not shown). The results from these two dot blots confirm that DNA probe PCR278 can specifically identify $M$ paratuberculosis from among 27 different mycobacterial strains and from a wide range of other diverse organisms. 


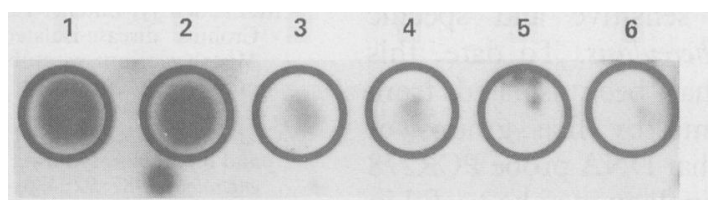

Figure 2: Testing the sensitivity of DNA probe PCR278. Dilutions of $M$ paratuberculosis genomic DNA were prepared and spotted onto a nylon membrane: (1) $10 \mathrm{ng}$, (2) $5 \mathrm{ng}$, (3) $1 \mathrm{ng}$, (4) $500 \mathrm{pg}$, (5) $100 \mathrm{pg}$, and (6) $50 \mathrm{pg}$ After hybridisation at $65^{\circ} \mathrm{C}$ for 16 hours with ${ }^{32 \mathrm{P}}$-labelled $P C R 278$ the membrane was washed with $3 \times$ SSC $(1 \times$ SSC: $0.15 \mathrm{M}$ sodium chloride; $0.015 \mathrm{M}$ sodium citrate, $\mathrm{pH}$ 7); $0 \cdot 1 \%$ sodium dodecyl sulphate, then exposed to to an $\mathrm{x}$ ray film for 16 hours at $-70^{\circ} \mathrm{C}$

\section{SENSITIVITY OF DNA PROBE PCR278}

A dot blot containing dilutions of $M$ paratuberculosis genomic DNA, ranging from $10 \mathrm{ng}$ to 50 $\mathrm{pg}$, was prepared. Hybridisation of this dot blot with labelled PCR278 resulted in the detection of positive signals with as little as $500 \mathrm{pg}$ of $M$ paratuberculosis genomic DNA (Fig 2). McFadden $e t$ al $^{7}$ calculated the genome size of $M$ paratuberculosis as $3.1 \times 10^{9} \mathrm{Da}$, correspondingly the detection of $500 \mathrm{pg}$ of $M$ paratuberculosis genomic DNA target sequence represents the detection of $1 \times 10^{5}$ genomes.

In an attempt to increase further the sensitivity of DNA probe PCR278 seven aliquots of $M$ paratuberculosis genomic DNA (1 ng-1 fg) were subjected to PCR amplification using primers P11 and P36. A $10 \mu \mathrm{l}$ aliquot of each PCR reaction was subsequently electrophoresed through a $2 \%$ agarose gel. Ultraviolet visualisation of the ethidium bromide (EtBr) stained agarose gel showed a band of the correct size (278 bp), amplified from as little as $1 \mathrm{pg}$ of starting material (data not shown). Sensitivity was further improved by Southern blotting ${ }^{18}$ this gel and probing the resultant membrane with ${ }^{32 P}$-labelled DNA probe PCR278 (Fig 3). The amplified 278 bp band was detected in lanes 1-6 $(1 \mathrm{ng}-10 \mathrm{fg})$. With Southern blotting the limit of detection was increased 100 -fold over that achieved by ultraviolet visualisation of an $\mathrm{EtBr}$ stained gel. This shows that DNA probe PCR278 can, in conjunction with the PCR amplification technique, detect as little as $10 \mathrm{fg}$ starting material (Fig 3; lane 6) of $M$ paratuberculosis genomic DNA, the equivalent of two genomes.

\section{Discussion}

The 1451 bp nucleotide sequence of IS 900 , an insertion sequence element repeated 15-20 times within the genome of $M$ paratuberculosis, has recently been determined.${ }^{14}$ Comparison of DNA databases to IS 900 showed an overall homology of $52 \%$ with IS110, an insertion sequence element identified in Streptomyces coelicolor. ${ }^{19} 20$ No homologies with other insertion sequences were observed. The strongest homology between IS900 and IS 110 occurs at their 3 '-ends, at both the DNA and the amino acid level. Evidence for homologies between IS 900 and a class of related insertion elements found in disease isolates of $M$ avium has been shown by Southern blot analysis (McFadden et al, unpublished results). Accordingly, we have tested DNA fragments originating from the 5 '-end of IS 900 for specific-

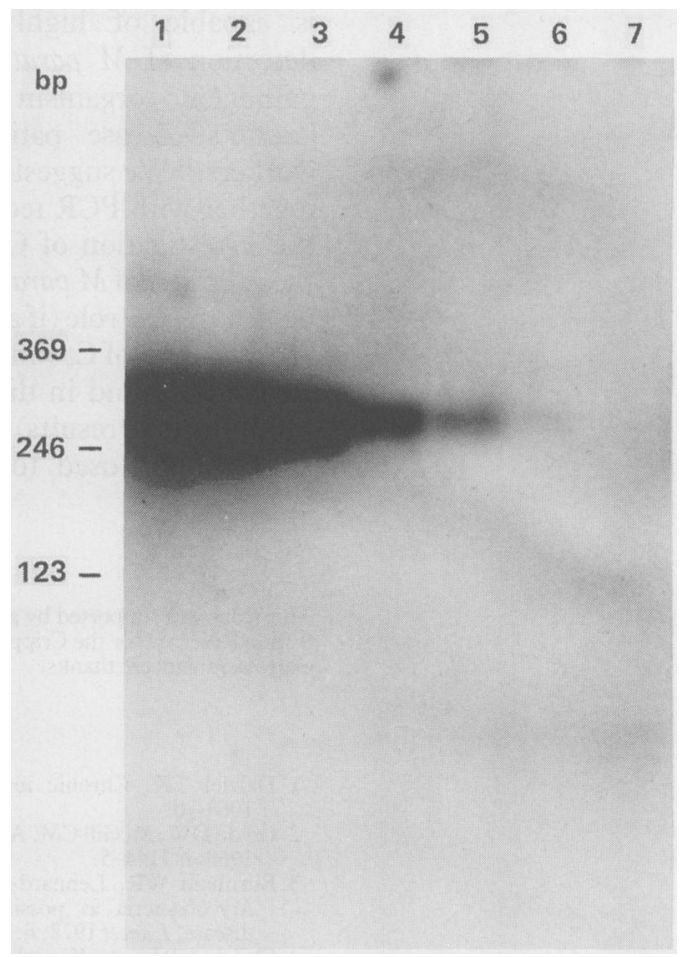

Figure 3: Southern blot analysis of PCR amplification products with labelled PCR278. Each lane contains one tenth of the PCR reaction mix. The original starting material in each PCR reaction was as follows: lane (1) $1 \mathrm{ng}$, (2) 100 $\mathrm{pg}$, (3) $10 \mathrm{pg}$, (4) $1 \mathrm{pg}$, (5) $100 \mathrm{fg}$, (6) $10 \mathrm{fg}$, (7) $1 \mathrm{fg}$. Hybridisation with PCR 278 was at $65^{\circ} \mathrm{C}$ for 16 hours and exposure of the $\mathrm{x}$ ray film was for 16 hours at $-70^{\circ} \mathrm{C}$.

ity for $M$ paratuberculosis. Unfortunately, the restriction site profile of IS900 (data not shown) does not allow easy isolation of a suitable 5 '-end fragment; consequently we have used PCR to isolate appropriate portions of the IS900 sequence. The two oligonucleotide sequences selected for use as PCR amplification primers in this study (P11 and P36) span the 5'-region of IS 900 and their use results in the amplification of a $278 \mathrm{bp}$ fragment. This amplification product (PCR278) was subsequently used as a DNA probe and our results show it can specifically distinguish $M$ paratuberculosis from a wide range of organisms, including members of the $M$ avium-M intracellulare complex. Hurley et al ${ }^{21}$ have recently described the development of a DNA probe for the detection of $M$ paratuberculosis; however, their probe was unable to differentiate members of the $M$ avium- $M$ intracellulare complex.

In a recent paper, Butcher et $a l^{22}$ described their failure to detect, by Southern blotting and DNA hybridisation with cloned mycobacterial genomic DNA probes, the presence of mycobacterial sequences in Crohn's disease tissue. They concluded that the failure of their study could be accounted for by a lack of sensitivity in the techniques used; $M$ paratuberculosis genomic DNA could not be detected at levels equivalent to one mycobacterial genome/100 human cells. Using the methods described in this paper, one of us (ZPM, unpublished results) detected one $M$ paratuberculosis genome/2500 human cells.

PCR is a powerful technique capable of amplifying specific target DNA sequences $>10^{5}$ fold. ${ }^{2324}$ Our results suggest that DNA probe PCR278, in conjunction with PCR amplification, 
is capable of highly sensitive and specific detection of $M$ paratuberculosis. To date, this pathogenic organism has been isolated from Crohn's disease patients by five groups of workers. ${ }^{24} \mathrm{We}$ suggest that DNA probe PCR278 together with PCR technology may be useful in the investigation of Crohn's disease tissues for the presence of $M$ paratuberculosis and will help to determine the role (if any) of this organism in the pathogenesis of Crohn's disease. Homologous IS elements, found in disease isolates of $M$ avium (unpublished results) are being sequenced and may also be used to assess the role of these organisms.

This work was supported by grants from the Wellcome Trust and Action Research for the Crippled Child to whom we would like to express our sincere thanks.

1 Dalziel TK. Chronic interstitial enteritis. BMF 1913; ii: 1068-70

2 Golde DW, McGill CM. Aetiology of regional enteritis. Lancet 1968; i: 1144-5.

3 Burnham WR, Lennard-Jones JE, Stanford JL, Bird RG Mycobacteria as possible cause of inflammatory bowel disease. Lancet 1978; ii: 693-6.

4 Chiodini RJ, van Kruiningen HJ, Thayer WR, Merkal RS, Coutu JA. Possible role of mycobacteria in inflammatory bowel disease. I. An unclassified Mycobacterium species bowel disease. I. An unclassified Mycobacterium species isolated from patient

5 Chiodini RJ, van Kruiningen HJ, Merkal RS, Thayer WR, Coutu JA. Characteristics of an unclassified Mycobacterium species isolated from patients with Crohn's disease. $f$ Clin Microbiol 1984; 20: 966-71.

6 Chiodini RJ, van Kruiningen HJ, Thayer WR, Coutu JA. The spheroplastic phase of mycobacteria isolated from patients with Crohn's disease. F Clin Microbiol 1986; 24: 357-63.

7 McFadden JJ, Butcher PD, Chiodini RJ, Hermon-Taylor J. Determination of genome size and DNA homology between an unclassified Mycobacterium species isolated from patients with Crohn's disease and other mycobacteria. $\mathcal{F}$ Gen Microbiol 1987; 133: 211-4.
8 McFadden JJ, Butcher PD, Chiodini RJ, Hermon-Taylor J. Crohn's disease-isolated mycobacteria are identical to Mycobacterium paratuberculosis, as determined by DNA Mycobacterium paratuberculosis, as determined by DNA
probes that distinguish between mycobacterial species. $\mathcal{F}$

9 Graham DY, Markesich DC, Yoshimura HH. Mycobacteria and inflammatory bowel disease. Results of culture. Gastroenterology 1987; 92: 436-42.

10 Chiodini RJ, van Kruiningen HJ, Merkal RS. Ruminant paratuberculosis (Johne's disease): the current status and future prospects. Cornell Vet 1984; 74: 218-62.

11 Patterson DSP, Allen WM. Chronic mycobacterial enteritis in ruminants as a model for Crohn's disease. Proceedings of the Royal Society of Medicine 1972; 65: 998-1001.

12 Morgan KL. Johne's and Crohn's. Chronic inflammatory diseases of infectious aetiology? Lancet 1987; i: 1017-9.

13 Hampson SJ, Portaels F, Thompson J, et al. DNA probes demonstrate a single highly conserved strain of Mycobacterium avium infecting AIDS patients. Lancet 1989; i: $65-8$.

14 Green EP, Tizard MLV, Moss MT, et al. Sequence and characteristics of IS900, an insertion element identified in a human Crohn's disease isolate of Mycobacterium paratuberculosis. Nucleic Acids Res 1989; 17: 9063-73.

15 Visuvanathan S, Moss MT, Thompson J, et al. Simple enzymic method for isolation of DNA from diverse bacteria. $\mathcal{J}$ Microbiol Methods 1989; 10: 59-64.

16 Green PM, Bentley DR, Mibasham S, Nilsson IM, Gianelli F. Molecular pathology of haemophilia B.EMBO $71989 ; 8$ : 1067-72.

17 Feinberg AP, Vogelstein B. A technique for radiolabelling DNA restriction fragments to high specific activity. Anal Biochem 1984; 137: 226-7.

18 Southern EM. Detection of specific sequences amongst DNA fragments separated by gel electrophoresis. F Mol Biol 1975; 908: 503-17.

19 Chater KF, Bruton CJ, Foster SG, Tobek I. Physical and genetic analysis of IS110, a transposable element of Streptomyces coelicolor A3(2). Mol Gen Genet 1985; 200: 235-9.

20 Bruton CJ, Chater KF. Nucleotide sequence of IS110, an insertion sequence of Streptomyces coelicolor A3(2). Nucleic Acids Res 1987; 15: 7053-65.

21 Hurley SS, Splitter GA, Welch RA. Development of a diagnostic test for Johne's disease using a DNA hybridizadiagnostic test for Johne's disease using a DNA
tion probe. 7 Clin Microbiol 1989; $27: 1582-7$.

22 Butcher PD, McFadden JJ, Hermon-Taylor J. Investigation of mycobacteria in Crohn's disease tissue by Southern blotting and DNA hybridization with cloned mycobacterial genomic DNA probes from a Crohn's disease isolated mycobacteria. Gut 1988; 29: 1222-8.

23 Saiki RK, Scharf S, Faloona F, et al. Enzymatic amplification of $\beta$-globin genomic sequences and restriction site analysis for diagnosis of sickle cell anemia. Science 1985; 230: 1350--

24 Chiodini RJ Crohn's disease and the mycobacterioses: review and comparison of two disease entities. Clin Microbiol Rev 1989; 2: 90-117. 